\title{
Uvanlig bivirkning av et vanlig legemiddel
}


En kvinne i 50-årene hadde i mange år hatt jernmangelanemi på grunn av uforklart stort tap av jern i urin (1). Hun hadde fått blodoverføringer og intravenøst jerntilskudd i 15 år, sist i form av jern(III)karboksymaltose i større doser.

Kvinnen utviklet så gradvis økende smerter fra korsryggen ut i begge glutealregioner. Blodprøver viste normalt kalsium-, lavt fosfat- og forhøyet ALP-nivå, PTH i øvre normalområde, normale 25-OH-vitamin $\mathrm{D}$ og 1,25( $\mathrm{OH}) 2$-vitamin D-verdier. MR-undersøkelse (STIR-sekvens) viste høysignalforandringer $\mathrm{i}$ begge sakralvingene og etter hvert på ileumsiden, tydende på betydelig knokkelødem (bildet til venstre). Det var oppklaringslinjer i sakralvingene som kunne gi mistanke om insuffisiensfraktur bilateralt. Helkroppsscintigrafi viste økt opptak i fremre del av os frontale på begge sider av midtlinjen, i flere costae, begge ileosakralledd og proksimalt i venstre tibia.

Hypofosfatemisk osteomalasi sekundært til intravenøst tilskudd av jernsakkarider er tidligere beskrevet (2). De små, elektrisk nesten nøytrale jernsakkaridene filtreres i glomeruli og forstyrrer reabsorbsjon av fosfat i proksimale nyretubuli. I tillegg forstyrrer de 1-alfa-hydroksylaseaktiviteten og forverrer osteomalasien ved direkte hemming av beindanningen.

Behandlingen består i å seponere tilskudd av jernsakkarider, eventuelt gi tilskudd av peroral fosfat og vitamin D (2). Heldigvis ser det ut til at nyretubulidysfunksjonen og osteomalasien er reversible, men alvorlige beindeformasjoner kan være permanente. Ved kontroll fem måneder etter seponering av alle jerntilskudd, var pasienten i bedring. MR viste regress av patologiske forandringer (bildet til høyre). Pasienten trenger imidlertid fremdeles behandling for jernmangelanemien og får nå en annen type intravenøst jerntilskudd. Transfusjonsbehovet varierer, avhengig av hvor ofte hun får jern.

Pasienten har gitt samtykke til at artikkelen blir publisert.

\section{Kari Lenita Falck Moore}

kari.lenita.falck.moore@unn.no

Odd Kildahl-Andersen

Randi Kildahl-Andersen

Universitetssykehuset Nord-Norge, Harstad

Geir E. Tjønnfjord

Oslo universitetssykehus

Kari Lenita Falck Moore (f. 1981) er lege i spesialisering $\mathrm{i}$ indremedisin og i blodsykdommer
Odd Kildahl-Andersen (f. 1946) er overlege, dr.med. og spesialist i indremedisin og i blodsykdommer.

Randi Kildahl-Andersen (f.1941) er overlege og spesialist i radiologi ved Radiologisk avdeling.

Geir E. Tjønnfjord (f. 1953) er spesialist $\mathrm{i}$ indremedisin og blodsykdommer. Han er avdelingsleder for Avdeling for blodsykdommer og professor i hematologi ved Institutt for klinisk medisin, Universitetet i Oslo.

\section{Litteratur}

1. Kildahl-Andersen O, Thorstensen K, Sagen E et al. En 40 år gammel kvinne med anemi. Tidsskr Nor Lægeforen 2006; 126: 2958-9.

2. Sato K, Shiraki M. Saccharated ferric oxideinduced osteomalacia in Japan: iron-induced osteopathy due to nephropathy. Endocr J 1998; 45: $431-9$.

Mottatt 19.4. 2012, første revisjon innsendt 12.8. 2012, godkjent 28.8. 2012. Medisinsk redaktør Merete Kile Holtermann.

Engelsk oversettelse på www.tidsskriftet.no 